\title{
A constante Kalfayan ${ }^{1}$
}

\author{
The constant Kalfayan
}

José Luiz Passos

\section{Uma foto}

Na foto de minha mãe que mais me incomoda, ela está estirada no colo de cinco homens sentados num sofá branco. Minha mãe traja um vestido goiaba, ou salmão, e sapatos de salto. Com uma perna cruzada por cima do joelho, a barra do vestido subiu quase toda, mostrando as suas coxas. Não há lance de roupa íntima nem nada do gênero, mesmo assim a imagem me incomoda. Saboia me disse: Menina, essa foto é genial, muito genial, do cacete mesmo, vamos usar? Mas falei que não. Ele acha, ou melhor, ele insiste que hoje em dia qualquer livro, com foto, vende mais. Mesmo que seja apenas uma, porque a imagem tem esse apelo, faz as pessoas imaginarem, Saboia falou. Elas querem ver mais, ouvir mais, comprar mais, as pessoas, quando veem uma foto.

Como respondi para ele, penso diferente. No meu entender, a história da minha mãe não depende das fotografias que ela própria tirou, nem menos ainda das muitas que circulam por aí com ela no palco.

Os cinco homens na foto de que Saboia tanto gosta foram importantes para minha mãe. Ela conhecia cada um deles muito bem. Talvez por isso sua expressão seja tão boba. Uma mão apoiada na perna de um magro, e a outra jogada por cima da cabeça, detrás dos cabelos, sorrindo de lábios apertados. Hoje, se fosse filmar um mero comercial, com certeza iriam lhe pedir: Alegria, amiga, sorria mais, é. Assim, abrindo mesmo. Mas eu nem imagino a grande Neide Laet fazendo isso.

Saboia me contou que a minha mãe era totalmente anticomercial. E que justamente nisso estava a força dela e, também, o interesse do meu livro.

\section{Ainda a mesma foto}

As canções que minha mãe cantava não eram baladas adolescentes, de amor perdido, incompreendido, impossível, ou da morte chegada antes da hora. Eram

Capítulo inédito do meu próximo romance, chamado "Um álbum para Lady Laet". histórias de gente buscando rumo, tramando um caminho juntos, acreditando no que, às vezes, não passava de ouro de tolo e, mesmo assim, sem perda da fé, buscavam outra rota na companhia de gente diferente. Novos amigos ou novos amantes, de olho numa segunda vida. As melhores canções de Neide Laet começam com "Ladeira", o meu hit preferido entre os seus primeiros. E o resto, como diz a própria letra, veio vindo porque vinha pelo meio.

Num dos últimos shows de minha mãe, dizem que ela de repente parou, foi sentar na plateia e passou a ouvir outra banda fazendo um cover, um longo cover, das músicas que ela costumava interpretar. O rapaz cantava uma oitava acima da própria voz, praticamente em falsete. A grande Neide se emocionou, me disseram, ouvindo trechos de uma carreira que, dali para trás, alcançava a marca dos trinta anos. E qual era o nome dessa banda? Saboia não soube dizer, falou que não se lembrava mais, que não era importante. Mas Neide não tinha se emocionado ouvindo esses rapazes? Como, então, que não era importante?

$\mathrm{Na}$ foto que Saboia gosta, as mangas do vestido salmão e o permanente não deixam dúvidas, é a década morta, com suas cores vibrantes. Rosa-choque, amarelo, preto e branco, cabelos armados, ombreiras, calças largas, pregas, muitas pregas, a jaqueta curta com luvinhas e, de vez em quando, uma boina ou um chapéu de feltro pendendo de lado. Por que os homens no sofá não se vestem com o mesmo apuro? Neide parece que vem de uma festa, e eles, da praia. Um inclusive usa óculos de sol, outro traja uma camiseta cavada, de mangas curtas, refeita a tesouradas.

Minha amiga Hani Kalfayan disse que os penteados desses homens eram uma grande salada de épocas. Por eles, apenas, não se poderia datar essa foto.

\section{Afinal uma amiga}

Hani me contou que foi visitar a outra família de seu pai uma única vez, há uns dez anos. Na época, ainda morava com o irmão menor. Os dois foram a Beirute conhecer a nova mulher com quem o pai teve 
mais três filhos. Hani disse que se sentiu estranha e, às vezes, péssima. Tudo lá era diferente, maior, mais claro até do que aqui em Los Angeles, de onde ela é. E todos olhavam demais para o casalzinho que seu pai tinha feito na Califórnia. Hani tem cabelos escuros, ondulados, longos, e a pele clara. Gosta de falar alto, mexendo os dedos compridos: Plus I'm so freakishly tall, ela costuma dizer, porque se acha esquisita, de tão alta. Devia ter sido jogadora de basquete ou tiradora de coco, brinquei. Mas ela não entendeu.

Foi Hani quem mais me deu força quando comecei o livro sobre a minha mãe. Estávamos nos mudando para a quitinete de West LA, e ela me ouviu falando com Saboia a respeito disso. Se seria ou não, difícil demais, para mim, que a conheci tão pouco, escrever sobre as canções de Neide Laet.

Hani disse que eu escrevesse. Pois olha o caso dela. Até sua viagem a Beirute, tinha vivido uma vida completamente normal, sem jamais pensar no passado.

\section{Marilyn}

Era raro minha conversa com as meninas da agência ser coisa mais séria. Já com Hani, depois de ouvir a história do pai dela, deixei de ficar com o pé atrás. No dia em que ela me contou isso, fomos sentar na frente do mármore com o nome de Marilyn Monroe. Deixei na jarrinha a flor que tínhamos apanhado no caminho.

As estrangeiras acabam saindo juntas e até morando umas com as outras, em apartamentos com três, quatro ou cinco de nós amontoadas, aguardando Daisy ligar com a proposta do dia. Quando ela me vê com Hani, Daisy nos chama de as Espertas ou de as Universitárias. Mas o nome verdadeiro de Daisy não é esse, ninguém sabe qual é. Às vezes ela telefona para Hani no meio da noite, querendo marcar alguma coisa já para o dia seguinte. Se fosse comigo toparia sempre. Até agora só fiz uma vez o píer de Santa Monica e o Griffith Observatorium, ou o corpo de bombeiros, na Sunset Boulevard.

Quando não temos nada programado e Daisy não liga, Hani me acompanha até o Memorial Park, onde enterraram a superloura. O sonho de Hani é ser antropóloga. Foi o que ela disse diante da paredinha de Marilyn: Anthropologist. Já o meu ainda não sei qual é. Talvez seja voltar para São Paulo, ou escrever um livro sobre a carreira de Neide Laet, o que segundo Saboia vinha a ser o mesmo.

Hani conheceu Saboia num bico que fizemos no píer. Ele grudou nela o tempo todo, e fez mal, porque não tem dinheiro para isso. Disse a ele que se a chata da Daisy ficasse sabendo dessa encostada, era eu quem estava frita.

No caminho de volta, tentei contar a ela um pouco do livro sobre a minha mãe. Aproveitei para comentar: Look, Saboia não descolou você, hm. Old guy. Fiz assim, com os dois dedos juntos, e apontei dos meus olhos para os dela. Hani parece que entendeu. Virou a bolsinha para o meu lado e abriu o zíper, mostrando o que tinha ali dentro. Era um tubo com spray de pimenta, dos grandes.

Rimos feito duas bêbadas.

\section{Capítulo um}

O tempo das grandes canções já tinha passado. Aos treze, Neide Laet bebia, fumava e sentia que era profunda na escadaria da praça Ramos. Mortenson não era o seu pai. As colegas também diziam que ele era para ser o seu pai, mas não era. Mortenson era o pai de Marilyn Monroe. Uma vez, a pequena Neide mostrou à mãe a foto de um senhor alto e magro, de terno cinza, bigode fino, e perguntou: É ele? O homem se parecia com Clark Gable, mas elas sabiam que aquele não era nenhum ator. Era Mortenson, o pai de Marilyn.

No registro do condado de Los Angeles, a mãe da futura atriz americana batizou a filha com o sobrenome do segundo marido, ou seja, Mortenson. Marilyn rejeitou isso. Preferia o do primeiro padrasto: Baker. A pequena Neide pode ter apanhado esse detalhe em casa, ouvindo a própria mãe ler na cama vidas de cantoras e atrizes, até pegarem no sono. Na infância, circulava nos aniversários e festas em família uma história parecida com essa, sobre o pai de Marilyn, contada às vezes pelos vizinhos e, outras, pelas próprias amigas da escola.

Quase todas as grande cantoras do rádio nos ensinam a mesma lição. Dirce di Falco, a ídolo de Neide, cujo modelo foram as estrelas da rádio Kosmos e da TV Excelsior, costumava se deixar fotografar apenas de olhos fechados, queixo erguido e boca entreaberta diante de um microfone Zenith com quatro hastes, em forma de diamante. Na sua melhor fase, a estupenda Neide moldava sua imagem a dedo, escolhendo o ângulo das fotos, um repertório às antigas, os escândalos que ela própria confirmava nas páginas de Sétimo céu. E embora nem sempre tenha sido uma diva fixada nos ritos do sucesso, houve um tempo em que subiu a outro nível e mostrou seu talento na companhia de quem, sem dúvida, tinha chegado lá. Todos já ouviram falar no que os artistas chamam de Momento, quando, tomados pelo desejo de ir além, eles reinventam quem são. $\mathrm{O}$ momento de Neide não chegou a ser propriamente um desses. Teve, com certeza, brilho intenso. Mas foi de quilate muitíssimo outro.

\section{Capítulo dois}

A respeito da jovem Neide, disse um crítico paulistano: Quem começa magrinha, polindo-se em coro protestante, jamais vai abocanhar um país cuja carne é o carnaval. 
Antes de chegar à adolescência, ela era chamada em família, na Vila Maria Zélia, de menina esquisita. Isto certamente pelos cabelos cor de ferro em volta do rostinho pálido, os óculos largos e cachos despenteados, as pernas finas. Cambitos, sua mãe lhe dizia: Coma, minha filha.

Neide crescia comendo o que um salário de balconista no Mappin deixasse sua mãe comprar. Na época, quem virasse à esquina da 9 de Julho, rumo à praça leste, cruzando por baixo da longa marquise de concreto, ia encontrar, no balcão ao centro do piso térreo, a ilha com espelhos e frascos em redor de uma mulher trajando tailleur cinza e blusa de gola verde. Era a mãe de Neide. O estande de maquiagem oferecia mostras de sombra, rouge e batom. Recém-lotada no setor, aplicando de cortesia os tons da estação, ela reinava das $9 \mathrm{~h}$ às $18 \mathrm{~h}$ num pequeno oásis com promessa de autoestima: Leve, querida, começa por aí o caminho do sucesso. Mas sua mãe tinha vindo grávida para São Paulo. Neide nasceu na semana prevista, a trigésima-nona, de parto natural no Hospital das Clínicas.

Naquele tempo, Matt Bo Grady já era um tipo mítico. Foi, sem dúvida, o ídolo da balconista no ano da barriga. Porém, há duas espécies de iluminados, os de onda e os de gênio. E os que ora se moldam pelos seus ícones, como garotos que copiam o penteado dos craques, moças posando para um espelhinho de bolso, explicam-se uns pelos outros. São frutos do mesmo fenômeno. Querem imitar as suas estrelas. Quando os olhos pousam na grandeza, as mãos buscam fazer uma cópia, é natural. A pequena Neide se vestia com os modelitos da fase limpa de Matt Bo Grady, embora este não tenha passado, segundo a crítica atenta, de um imitador menor de Elvis. Nisto seguia um longo rol, pois já são muitos os duplos do Rei. Assim mesmo, o tal Bo Grady tirou do peito da mãe de Neide pancadas fortes e, com elas, lágrimas amassadas num lenço rendado, coleção Mappin. E tamanho gesto deveu-se, apenas, a uma balada dessa época de tanta dureza: "Never your love again".

\section{Capítulo três}

Afinal, vingou o esforço Mappin da mãe, a verve do coro na igreja batista, o molde do pop tosco em Matt Bo Grady. São esses os verdadeiros traços da inconfundível voz de Neide Laet. Mas foi "Cidade irresoluta", o maior hit de sua carreira, que lhe rendeu o título de Lady, em matéria consagradora da revista Manchete. "Musa e Bandeirante", a publicação carioca estampou em capa com foto.

Ora, em fevereiro Los Angeles se parece ainda mais com o mês de junho, em São Paulo. Lady Laet se preparava para vir à Califórnia gravar seu novo álbum, quando o crime do Itaim tirou a diva de uma rota que, para muitos, já soava escandalosa demais. Passado o tempo, a maioria já se esqueceu dos fanzines daquele ano. Num aceno a outras épocas, o álbum se chamaria Lady canta São Paulo. Mas, então, cidade irresoluta por quê? Nas palavras do próprio hit, vejamos o que irresoluto quer dizer. É o que ainda não foi resolvido, aberto, ansiado, prestes a, solúvel apenas no fim, estado pendente, na ponta da língua, limbo ou eterna espera, retardo que aguça a urgência, bem como, é claro, no vulgo, cruel cemitério dos corações. Eis o irresoluto dessa cidade.

Aí está o bairro de Neide, a Vila Maria Zélia, com a casa dos batistas posta diante da capela de São José. Seu hábito de erguer a voz, de queixo baixo, nos graves, até o brilho de olhos ao alto, nos agudos, estilhaçando uma sílaba de palpitar, barbas ou arranha-céu, vem do apreço pelo gospel e da imagem de uma garota Marilyn, malcomportada. Na viagem a Los Angeles ela beijaria, como muitos beijam, a lápide da loura Monroe? É provável que sim. Neide sempre acreditou que ambas eram filhas do mesmo pai. Mas não houve tempo para tanto: vox, vanitas et finis. Como diz a canção recente, depois de tanto verbo a pessoa morre. Matamos Lady Laet, nossa mais perfeita intérprete. Ou melhor, a ser justo com a estrela, não há dúvida de que ela própria quis consumir-se, só e exclusivamente, apenas aí, nas grandes vilas e subúrbios de São Paulo.

\section{Beirut ou Beirute}

Mas se Lady Laet era excêntrica, os Kalfayan não ficam para trás. Não imaginava que fim tivesse levado o pai de Hani, e talvez nem ela mesma soubesse. Isso, é claro, até recentemente. Depois que nos mudamos para o apartamento em West LA, Hani passou a ouvir canções de minha mãe.

Às vezes eu brincava que éramos irmãs em segundo grau. Saboia me disse que, pela Câmara de Comércio, Los Angeles e Beirute eram cidades irmãs. E que São Paulo e Los Angeles também eram. Daí, Beirute e São Paulo são coirmãs, ou irmãs em segundo grau, como nós duas, falei. Mas Hani não via graça nisso.

$\mathrm{Na}$ semana da festa, depois de fazer um bico em Beverly Hills, ficamos em casa comentando os carros que os manobristas guiavam de coletinho. De repente ela abriu a bolsa, puxou uma fotografia e disse: My dad. Não foi rápido assim, antes tomamos um vinho. Mas é como lembro dessa noite. Doutor Kalfayan aparece jovem, de calças escuras e camisa clara. A foto deve ter mais de trinta anos. Foi então que Hani voltou a tocar no assunto sobre o que queria fazer fora da agência: Anthropologist. Falou que o pai viveu com ela, o irmão e a mãe somente até Hani fazer doze anos, depois voltou para o Líbano. $\mathrm{Na}$ foto, ele está de óculos escuros e mãos na cintura. Por 
trás tem um avião de duas hélices e, ao fundo, um prédio quadrado, baixo, todo branco.

Apanhei na geladeira outro vinho e fomos para a janela olhar os carros dobrarem à esquina. Era uma madrugada de céu aceso, opaco, com o ar fresco borrando os luminosos na avenida.

Meu inglês não é bom. Hani também não fala português: My dad, ela repetiu. Entendi que na foto seu pai estava fora, viajando, isso antes de doutor Kalfayan conhecer a mãe dela. Talvez até mesmo antes de ele ter vindo para os Estados Unidos, pois o lugar não parecia ser aqui. Passamos um tempo caladas e, então, perguntei se podia colocar uma música. Apontei para o computador, depois para os ouvidos e fiz um Ok. Hani sorriu. Mostrei o Ok com um polegar para cima, como faço. Já ela, usa esse dedo e o indicador num $O$, e estira os outros fazendo o número três. Então, pelo menos nisto somos diferentes uma da outra.

\section{Samba}

Escolhi um dos álbuns de Lady Laet e coloquei para tocar. Era o segundo que ela tinha gravado, um chamado Aposta. Saboia disse que, no começo, quando minha mãe passou a compor as próprias canções, ela buscava parceria entre os da velha guarda. Daí saiu com Matias Meira um primeiro samba de orquestra, "Aposta na tristeza", mas para conjunto de rock, com batida quatro por quatro. Não tentei explicar a Hani o que era isso. Disse apenas: Very sad, um samba. Virei para ela o laptop com a imagem da capa. Ela ficou olhando. Aumentei o volume e apontei: My mom.

Hani veio examinar a tela de perto. Sorriu, abrindo a boca com exagero: Wow. E fez um Ok com o polegar para cima, dos meus. Talvez com isso quisesse dizer que tinha gostado muito, e imaginava o quanto eu devia me orgulhar dessa foto da minha mãe, a única mulher do grupo estampado na capa do álbum. Good for her, ela disse.

Mesmo assim não expliquei como me sentia em relação àquela pose. Nem, é claro, o que significava um samba ou uma aposta. Isso teria dado um belo jogo de adivinhações. Aumentei o volume, coloquei o computador numa cadeira e voltamos para a janela, ouvindo a música, tomando vinho.

\section{Aposta na tristeza}

As melhores canções

muitas se compõem

de melancolia e retiro.

Na maioria é puro humor

o que julgamos razão.
É temperamento o que parece engano.

É enfermidade o que chamam virtude.

São efeitos da tristeza

operados na melodia

que nos obriga a seguir

o violento coração e nunca

nos deixa a sós no presente.

Ocupados vamos com o passado,

indefinível, cheio de melancolia,

na incerteza das dores

que estão por vir.

Aposta na tristeza todo dia.

Aposta que ela é a sua guia.

\section{Doutor Kalfayan}

Berkeley criou a cátedra de engenharia de viagens faz pouco mais de um ano. A colheita foi feita, o verão passou e ainda não fomos salvos: Jeremias, capítulo 8, versículo 20. Essa foi a epígrafe que doutor Kalfayan, o pai de Hani, escolheu para a conferência de inauguração.

Ele defendeu a criação da cátedra numa palestra no teatro do campus. Mas na hora de começar não estava presente. Em vez de doutor Kalfayan baixou uma tela entre a boca de cena e os primeiros assentos. Ele tinha partido às $20 \mathrm{~h} 20$ da estação El Pueblo de Los Angeles, onde há um mural de Diego Rivera, e, usando um telefone celular, da cabine do trem-bala transmitiu a palestra quase toda, com as vinhetas e suas sensações. Antes de projetar um holograma no vão do teatro, doutor Kalfayan entrou pela porta principal, por trás da plateia, e desceu o corredor entre as fileiras, até o palco. Tinha feito o trajeto de Los Angeles a Berkeley em oitenta minutos, de porta a porta, sem voar, sem filas nem espera, andando, falando, comentando as sensações com centenas de pessoas que esperavam por ele sentadas. A mesma viagem, de carro pela antiga Highway 1, margeando o Pacífico, podia levar nove horas. Kalfayan encerrou sua fala pontualmente às $21 \mathrm{~h}$.

A última vinheta que mostrou foi a imagem azul fosforescente de um busto cabeludo, em 3-D, que ora parecia um homem colonial, ora um macaco de olhar tristonho, meio volto, num perfil a três quartos. A legenda embaixo da figura, flutuando logo acima das cabeças na plateia, dizia apenas: A nondescript. Um indefinível.

\section{A constante Kalfayan}

Engenharia de viagens é um nome que dá a ideia errada da teoria do pai de Hani. Na palestra ele explicou que "Um indefinível" era o busto de um macaco empalhado pelo naturalista Charles Waterton, em 1818, 
para se parecer a um lorde das primeiras eras ou um cavaleiro arturiano. Na volta da América do Sul, de posse do macaco, Waterton ficou preso na aduana de Liverpool sem conseguir explicar a coleção bizarra dentro dos seus baús.

Doutor Kalfayan falou que numa visita uma coisa tenta se parecer a outra, o sucesso está na imitação do conviva. Quem senta à mesa, usa os talheres como o anfitrião. Viaja para fora, quer saber onde os dali vão. Em Roma como os romanos, doutor Kalfayan disse, a visita é uma arte da cópia. Um brinde deve ser acompanhado. Apertos de mão, tom de voz e risos pedem reciprocidade. Qualquer um quer ser bem-sucedido no trato e causar boa impressão. Hani gosta de repetir isso. Que sucesso é controle, e controle é uma boa reprodução, com toda a consciência de ser reprodução.

No começo, o pai dela não era considerado um cientista sério. Mas seus algoritmos davam resultados mais próximos à intenção dos usuários. Digite urso de pelúcia e receba de volta links, banners e vídeos com sugestões a gosto. Perfil, língua, localização, histórico, quem navega nas redes se torna passível de uma cópia cada vez mais perfeita. O governo contratou Kalfayan para desenvolver um programa de contato entre estranhos. Dois diplomatas adversários, soldados inimigos, um homem e um organismo não identificado, o industrial e seu operário rebelde, as diferenças podem ser enormes, Kalfayan disse. E pensei no velho Brasil, em São Paulo. Se um ladrão viesse me forçar, e eu falasse usando o sotaque dele e mostrasse que gostava do que ele gosta, tudo ficaria bem: A foe at home is no longer a foe. Um inimigo, à vontade, faz amizade. Ele pensaria que, estranhamente, já éramos conhecidos. Nessa igualdade está a força de uma constante. O pai de Hani encerrou a palestra com o tal indefinível dele: Attention, ele disse. A maior arma de todas não é um foguete, mas a aparência de uma completa semelhança. Por isso, o verdadeiro amigo precisa ser nosso mais perfeito oposto.

\section{Capítulo seis}

Comentando a noite em que Neide Laet completou a gravação de Aposta, o dono da Som Geral, o carioca Syd Gutierrez, levanta uma hipótese válida. De onde vem o toque tão diferente desse álbum? Ele próprio responde que estava na ginga de uma estreante veterana. Tendo interpretado canções do repertório clássico, Neide agora assinava como compositora, trazendo um pouco dos de antes para mais perto de sua época. Seis das catorze canções do álbum eram dela, sozinha ou em parceria. Uma nova versão de "Ladeira", "Aposta na tristeza", "Fim de ano", "Mútua admiração", "Bicho Brasil" e, finalmente, "Conjunto habitacional".
A contracapa mostra um homem de cabelos compridos numa estrada que baixa por uma colina e, ao fundo, uma pequena cidade de interior, fora de foco. Essa era a imagem da contracapa. E na famosa capa, Neide Laet vai reclinada no colo de cinco homens sentados num sofá branco.

Mas a principal diferença está no estilo das canções. Marcada por riffs à rockabilly, com guitarras dobradas em ambos os canais, "Aposta na tristeza" abre com um longo trecho instrumental. Quando afinal Neide começa a cantar, As melhores canções muitas se compõem de melancolia e retiro, quase dois minutos e meio em overdubs já haviam preparado a entrada do contrabaixo e da bateria, acompanhados do cavaquinho. Os riffs da abertura, em repetição cadenciada, começam por um acorde aumentado de sétima, uma decisão rara no rock da época. E o aspecto groove, em compassos dedilhados a palhetadas, dá a "Aposta na tristeza" um quê estrangeirado, mesmo que ainda no bojo do velho samba. De onde vinha isso?

A banda se eletrificou, diz Syd Gutierrez. Coisa mais linda essa guitarreira toda. Tamanha era a participação do instrumento, nos arranjos, que muitos apontaram Mão de Gato, o lead guitar de Neide, como o homem da contracapa. Mas não era. Mão estava sentado na foto de capa, com os braços por baixo da cantora. A contracapa mostra apenas um modelo masculino, ao gosto da época, cabeludo, posando de costas.

$\mathrm{O}$ álbum foi um estouro. Porém, estouro no sentido interior, de arrebentação. Um grito, como Help. E Aposta mostrava como as coisas iam mudar. Pois já não era sem tempo. Como diz outro hit da época: My baby does it hanky-panky.

\section{Capítulo sete}

Anos depois, a própria Neide Laet relembra esse momento. No documentário Quem canta nossa canção, ela comenta o início da carreira e a influência do samba. São três mulheres entre os quase quarenta entrevistados.

Você enfrentou dificuldades? A entrevistadora, fora de cena, quer saber.

Dificuldades, Neide repete, e faz silêncio. Quem não enfrenta, querida? Para esse seu filme, você não se bate com as suas dificuldades?

Há um corte na montagem.

Agora, filmada a contra plano, ela menciona o nome de Cartola, e um dos seus sambas começa a tocar. Neide traja uma túnica com estampas florais e óculos de sol. Diz que saiu de casa aos catorze anos e, assim mesmo, continuou aprendendo, tocando, subindo a ladeira, por assim dizer, para ouvir o que gostava.

Que ladeira, a entrevistadora pergunta. Aonde você ia? 
Neide não responde, começa a cantarolar o refrão de "Aposta na tristeza", incluído no single que naquele ano chegou ao topo das listas.

$\mathrm{Na}$ cena ela está sentada numa cadeira de vime, em forma de concha, suspensa por uma corrente presa ao teto. Cobrindo a parede por trás dela há um tapete de sisal bordado com plantas e animais. Neide canta baixinho, tamborilando os dedos no braço de vime, e encerra após o verso: $\mathrm{Na}$ incerteza dos amores que estão por vir. Não repete o refrão que dá título ao samba nem diz mais nada, apenas ri, fechando os olhos devagar. Então, como uma garotinha batendo palmas para si mesma, Lady Laet se reclina na cadeira, balançando-se, e sorri de novo, antes de sair de foco naquela que seria a sua última entrevista.

\section{The big party}

Let's have some fucking fun in this shithole. Às vezes Hani se refere às coisas de maneira engraçada. Disse que a noite ia ser um estouro: It's our big party coming up, Lucy. Então, Ok, Hani. Falei que queria ajudar: I help. Não imaginava que àquela altura ainda fôssemos estar ajeitando o apartamento, nos acostumando a morar sozinhas, num lugar ainda mais apertado que o de antes, onde ficaram as outras meninas. Los Angeles é um país derramado num tabuleiro xadrez. As avenidas são longas, retas, os bairros distantes.

Para a festa, eu e Hani tínhamos escolhido a mesma fantasia. Na quitinete mal cabem quinze pessoas, ela chamou quarenta. Então convidei Saboia. Quando ele entrou, disse apenas, Uau, e ficou me olhando, vendo meu cabelo estirado, azul, minissaia e top cintilante, os óculos sem lentes e uma gravatinha no pescoço. Não nos víamos há uns dois meses. Mas foi como se perguntasse, já acabou o livro de sua mãe? Saboia veio para a festa de camisa Polo esticada, um número menor que o tamanho certo, pulôver amarrado na cintura e um tênis de couro preto, na moda esporte-fino de quantos anos atrás, vinte? Opa, Lou-see, ele disse. E aí? Então passou a vista pelo apartamento. Os amigos de Hani continuavam bebendo, calados, sacudindo as cabeças no ritmo que vibrava a janela.

Hani não dança. Estava de olhos fechados, no meio de um grupo de três ou quatro, inclusive Pablo, ela girando os punhos por cima dos cabelos, dobrando os joelhos como se fosse ficar de cócoras, só para se erguer novamente e estirar os braços para o alto. Devia estar imitando alguém ou uma ginga das baladas antigas, que ela fazia ainda melhor: I don't really dance. Daí Hani me olhou de lá, apontou e o grupinho dela riu. Talvez porque nossa roupa fosse igual. Mesmo assim não tentei explicar a Saboia o que era isso, As Bibliotecárias: The
Librarians, get it? Não ia fazer diferença nenhuma. E, do nada, Saboia entrou naquela zona só dele, olhando tudo em silêncio, os lábios prendendo o riso, querendo dizer alguma coisa. O que sei é que seria, com certeza, a coisa errada.

\section{Sozinha}

Saboia conheceu minha mãe ainda jovem e imediatamente começou a fazer a grande Lady. Ele costuma dizer que seu trabalho é fazer o artista. "Ladeira" tinha saído um ano antes, em compacto, e depois no LP Aposta. Na época já se podia falar em duas Neides, a das orquestras e a das bandas. E foi na estrada, com a Banda Menor, que ela encontrou Saboia pela primeira vez, num festival em Santos. Isto, segundo ele próprio, em 1975, quando então assinaram o primeiro contrato.

Era só o começo, mas uma arrancada já por cima. E como Joy, dos The Setembrists, Columbus, Columbus, de Phil Tinker and the Toddlers, e Birds of Fortune, de Phoebe Brunner, Aposta foi daquelas estreias que faz com que você queira ter o LP o mais rápido possível, antes de qualquer um, e, som nas alturas, sentar na poltrona com o encarte no colo, o cabeludo fazendo uma pose de costas, descendo a ladeira dele, enquanto, na capa, a sua mãe se estirava no sofá por cima da banda inteira. Porra, Saboia disse. Eu fiz a Lady Laet, não fiz? Esse primeiro dela e mais quatro. Hein, Lucineide? Cadê a merda desse seu livro?

Saboia bebericava uma cuba libre de canudo. Eu disse apenas, vai sair querido. Vamos tomar um café, quero the mostrar uma parte. Mas, é claro, ainda não tinha nada para mostrar. Ele ficou me olhando, enquanto eu soprava bexigas cor-de-rosa como salsichas, daquelas que os animadores usam para fazer bichos, chapéus, espadas. Ele via minhas mãos rolando e atando as bexigas e ia de volta para as telas que Hani pôs na sala, com os vídeos dela. Cadê sua gêmea, Lou-see? Não respondi, continuei com o que minha amiga tinha pedido. Saboia ficou curtindo a vista, torcendo para que nos nozinhos eu estragasse $\mathrm{o}$ aplique que a manicure de Hani tinha me feito de favor.

Todas sabem que nas unhas prefiro cores frias, como água-marinha, violeta ou azul-celeste. Já Hani, as cintilantes, como ouro Glow, alumínio e telha-pop. Quando trocamos os esmaltes, as meninas comentam que ficamos com as mãos uma da outra. E depois também tem Daisy, que de vez em quando liga e nos manda em dupla, para os bicos, com ordens para se vestir isso ou aquilo combinando, daí lá vêm unhas, extensões, cílios, tudo igual. Mas ela não tinha sido convidada para a festa. Tem vezes que Hani nem sequer atende os telefonemas de Daisy: That bitch, ela diz. Ah, vaca. 


\section{A redução de Hani}

Há muitas maneiras de se descrever uma festa. Difícil é saber por onde começar. O único comentário de Saboia, a respeito, foi o de sempre. Tua amiga é purpurina pura, putz, podes crer, isso aqui é o berçário de Satã. Foi só. Saboia tem o triplo da idade de Hani, mesmo assim ainda baba. Acho engraçado um homem como ele querer competir nas atenções com gente feito Pablo.

Quando ele entrou, a música que estava tocando era "Dancing with myself", uma versão nova, lenta. E ficou ótima, Saboia disse, com backing feminino e um órgão Hammond dando um timbre de gospel, tinindo, ele falou. Saboia pensava nos arranjos de sua época. Então fomos até a janela, a pequena-corrediça: The sliding slut, como diz Hani, que é a única maneira de se ventilar a quitinete. Ficamos olhando os carros cortarem o sinal, a maioria de cor escura, quase todos guiados por gente sozinha.

Saboia de vez em quando olhava para dentro, buscando Hani. Pablo via as olhadelas dele. Esse tatuado é muito cafajeste, Saboia disse. Hani não estava ali, dela tinha somente o loop do vídeo para o streaming com os umanoids. Pablo chama isso de Redução, fazer a redução da pessoa que vai ao ar. Ele filmou nós duas andando e também paradas, de frente, de costas, dos lados, eu e ela de calcinhas. Mas só Hani aparece nua, com o corpo que Pablo deu a ela depois da tal redução. A cabinet é deles. Quem quer ver, paga a eles. Pablo administra as visitas em rede. Orra, que casal, hein? Esse foi o outro comentário que Saboia fez, de queixo caído, balançando a cabeça. O velhinho não via razão naquilo.

Mas eu vejo. Pablo e Hani fazem dinheiro com a invenção deles. Um dia ela vai poder mandar Daisy para o espaço. Talvez um dia até chegue a ser o que realmente quer: Anthropologist. Não é o que vive dizendo? Então, as cabinets na realidade servem para alguma coisa.

\section{Mulholland Drive}

O que primeiro se nota é a batida rouca das guitarras dos Rolling Stones. Aos poucos se ouve o vocal, e os faróis do carro clareiam o pavimento em longas faixas amarelas. A música pisca no equalizador do painel. Mick Jagger canta: When I'm drivin' in my car. And that man comes on the radio. O volume aumenta, então aparece alguém ao volante, dirigindo sozinha. Vemos que é uma moça, ou uma mulher jovem. É Hani, e nesse instante ela acelera o carro.

Os pneus derrapam na curva fechada. Não há mais nenhum outro veículo por perto. Os faróis iluminam muros, jardins e o vão sob as árvores à beira da pista. Hani se olha no retrovisor. Sua maquiagem está borrada, as olheiras escuras escorrem pelas maçãs do rosto. Ela obviamente tinha chorado. O retrovisor indica em leds verdes a direção e a velocidade do carro, Northwest 57 mph, rápido demais para a sinuosa Mulholland Drive. Uma placa com o limite de 30 milhas por hora aparece à direita e some. Visto de cima, de ambos os lados há uma malha de luzes vermelhas e brancas riscando canais na planície entre as montanhas.

I can't get no. Satisfaction. 'Cause I try. And I try. And I try, e Hani puxa a alavanca de marcha para o lado, acionando o câmbio manual. O painel acende com um ping sonoro: Auto Transmission Off. Ela pressiona um botão amarelo no console e outro ping luminoso soa: Intelligent Suspension Off. Hani tem os olhos fixados no escuro à frente. He's tellin' me more and more. About some useless information, Mick Jagger canta, ela passa o dedo no monitor do console: Computer Navigation Off. E com o polegar aos lados do painel, ping, aperta duas vezes. Antilock Braking System Off. Ping. Dual Airbags Off. E ele canta: Supposed to fire my imagination. I can't get no. Oh no, no, no. As guitarras param de repente, soam apenas as batidas secas da bateria. Hey hey hey, that's what I say. Agora, no close-up, Hani tem um ar petulante. I can't get no. Satisfaction. O volume aumenta aos poucos. I can't get no. I can't get no. E como quem tem raiva, ou vai à desforra, ela gira o volante com toda força e o carro sai abruptamente da pista.

\section{Satisfação garantida}

Ele destroça o guardrail. As rodas deslizam no acostamento de barro. O ruído do motor aumenta. Sobe uma nuvem de poeira amarela, e dessa nuvem, de dentro dela, o carro salta da colina numa parábola em câmera lenta. 'Cause I try and I try and I try. São quatro segundos em voo contra o tabuleiro de luzes que é Los Angeles, ou el-ei, como dizem por aqui.

A música tinha parado no início do mergulho rumo ao fundo da colina. De repente recomeça. Soam guitarras em riffs tão conhecidos que bastam dois acordes para identificar que se trata da mesma canção. I can’t get no girl reaction. Oh no. No, no, no. E uma nota grave, numa batida com a mão aberta, em cordas abafadas, marca o instante em que o carro esbarra no chão.

Chega primeiro com as rodas dianteiras, em câmera lenta, depois com as traseiras, num lugar que parece uma clareira rodeada de arbustos. Sobe uma nuvem de pó iluminada pelos faróis, a cento e cinquenta metros abaixo da Mulholland Drive. E Mick Jagger: When I'm watchin' my TV. And that man comes on to tell me. How white my shirts can be. A tomada se aproxima do carro e, pela janela, vemos Hani a meio plano. Ela está tranquila, de braços cruzados, a cabeça apoiada sobre os cotovelos por cima do airbag, que parece um imenso travesseiro fofo. Hani 
sorri discreta e tranquila, dorme embalada pelo refrão que encerra a música após o famoso fading: No satisfaction, no satisfaction, no satisfaction. Nesse exato instante a câmera recua e uma legenda aparece embaixo do carro. Choose your path. XGS 300. Drive with satisfaction.

\section{Comercial}

De repente fez-se um silêncio na festa. Era o fim do comercial em que Hani atuou guiando o carrão. Até hoje ela fala nisso: Fucking genius. Ali pintou muito dinheiro para ela. Como depois me disse Saboia, o vídeo parece mais uma espécie de pague e vá-com-deus da parte da auto-indústria moderna, mas amparada no velho rock and roll.

Eu tinha tirado o telefone da sala e deixado no fundo da gaveta de toalhas. Se alguém ligasse, ninguém escutaria. Daisy podia tentar o quanto quisesse. Todo mundo seguia prestando atenção aos detalhes que Hani apontava no loop do vídeo. Pablo disse que, em pleno voo, o carro detectou a queda e reativou os aparatos de segurança, salvando a moça. Quando disse: Saving the girl, Hani riu, eles se olharam, e Pablo lhe deu um beijo na boca, com a língua rodando entre os dentes dela. Saboia fez uma cara de nojo. Era sua forma tacanha de mostrar os ciúmes que não deveria ter. Estava deslocado. Não tínhamos mais assunto. Eu ia apanhando os copos de plástico que os amigos de Hani deixavam nos quatro cantos da quitinete. E talvez nem valha a pena mencionar o que aconteceu depois.

Saboia ficou alto, tinha bebido demais. Disse que aquela música era uma merda: This is shit, e apontava para a tela do vídeo. As pessoas se viraram para ele: Shit. Shit. Just shit. Falava de olhos fechados, e disse num inglês embrulhado, essa música glorifica os barbitúricos e a indiferença. Quem canta hoje o coletivo? A dor verdadeira, as saudades: Missing one's place in the world, hein? Uma canção de quatro acordes e três instrumentos chega longe só porque é em inglês. If you sing in English you get far. It's a success. O sucesso é da língua, vem da mídia. E então ele disse que Lady Laet era melhor do que Mick Jagger. Olhando para mim: Muito melhor, porra. Quem recusa a grande mídia morre num cantinho de terceiro mundo. E aí foi quando, para minha surpresa, ele apanhou meu laptop e colocou para tocar "Na cabana de Pai Tomás".

\section{Na cabana de Pai Tomás}

No outro dia, acordei tarde. Tínhamos tomado a última garrafa de vinho na madrugada. $\mathrm{O}$ último a sair foi Pablo. Depois da festa, se trancaram no quarto fazendo baby humanoids. De manhã ele saiu apressado.
Bye-bye, falei. Ou melhor, Hani fez com que eu falasse: Say goodbye, Lucy Nay Dee. Então dei meu tchauzinho. Daisy já tinha deixado um recado para Hani. Ela ouviu o recado, tomou uma xícara de café e foi ao banheiro. Sentei no sofá e peguei doutor Kalfayan em cima da mesinha. Queria ver se tinha alguma coisa no verso. Tirei a foto do porta-retratos e ali atrás dizia apenas Beirut, sem o $E$ no final. Mas eu já sabia que ele era de lá.

Quando Hani saiu, fui curtir a quitinete sozinha. Era como nos domingos, quando às vezes colocava um samba e sentia uma coisa diferente, longe daqui. Hani não entende a distância que há nisso, uma tristeza, um pesar pelo que nem sei se passou, mas que está ali, na voz, no timbre, na letra. Very sad, um samba. Ela parece não ver diferença entre as canções. Então fui escutar de novo aquela que Saboia tinha colocado para tocar ontem.

\author{
Os dias vazios e iguais \\ andam pela cidade. \\ Mas no ano passado, \\ na cabana de pai Tomás, \\ vivi duas semanas de felicidade. \\ Duas semanas de felicidade, \\ só duas vivi fora da cidade. \\ Na cabana de pai Tomás, olha aí \\ vocês, ê pai, fora os dias vazios e iguais.
}

Eu quero é samba, eu quero a sorte, eu quero é blues. Eu quero é samba. Eu quero a sorte. Eu quero é blues.

\section{Capítulo dez}

O primeiro brasileiro a se apresentar no Festival de Montreux, na Suíça, em 1978, não foi Gilberto Gil, como erradamente acabou registrado na história de um dos mais importantes palcos do jazz e da world music. Dois meses antes da apresentação do cantor baiano, um guitarrista paulistano, magro, de rosto pipocado, entrou sozinho empunhando uma viola de 12 cordas, amplificada por dois captadores e com um furo no bojo de madeira. $\mathrm{O}$ instrumento foi apelidado de Furiola, porque o buraco tinha sido feito pelo próprio músico, num acesso de fúria.

O nome dele é Luciano Gaviria, mas ninguém conhece Gaviria pelo nome. Ele é conhecido, na ficha técnica dos discos, como Mão de Gato. Seu nome alude à extrema habilidade com que Mão domina as cordas. Ele entrou dedilhando o que a Banda Menor chamava de take 2 de "Na casa de pai Tomás". Eram três minutos e meio de improvisações percutidas à samba, com o punho da mão direita batendo no bojo do instrumento. Tocando, ele foi até a boca de cena, onde estavam a base do microfone e uma fileira de pedais para guitarra. Mão olhou para baixo, continuando a improvisação, e ligou um pedal sound 
delay. Pisou de leve no aparelho e começou a dedilhar mais rápido, com puxadas leves e acordes agudos na base do braço da viola. O pedal repetia as notas a cada fração de segundo, numa cadência crescente com fading retardado. A impressão cumulativa era a de uma cascata de moedas ou gotas de vidro.

Foi então que Neide Laet entrou no palco sussurrando: Eu quero é samba, eu quero a sorte, eu quero é blues. No registro do LP Neide em Montreux, com foto de capa por Pedro Bel, a banda é totalmente abafada pelos gritos da plateia, que soa como um mar quebrando nas pedras. Aos poucos ouve-se Lady repetindo o refrão, aumentando a voz, enquanto Mão retoma a melodia que marca a abertura da letra: Os dias vazios e iguais andam pela cidade, mas no ano passado... E, de repente, os aplausos apagam os gritos da plateia e a voz da própria cantora.

\section{Capítulo onze}

Uma vez que um fato sucede é fácil dizer que era previsível. Já são bem conhecidas as numerosas versões a respeito da inevitabilidade da morte de Neide Laet. Cobrem uma vasta gama de conjecturas e interpretações, mas basicamente estão calcadas numa crença inerente à ideia da predestinação.

Há, por um lado, a visão de Neide como um bluesman de fado traçado na própria voz mortiça, ou como um roqueiro radical, com o pé no samba, unindo de norte a sul a ideia da vida extinta no flash de uma canção de amor. Também há quem pense que seu destino estava escrito nas estrelas, e que estas mostravam como, quando e onde ela morreria, ou ao menos davam indicações de seu potencial para a autodestruição e sinais da proximidade desse desfecho. Em geral, citam três jotas, Jimi Hendrix, Jim Morrison e Janis Joplin, JJJ, em contraposição astral ao KKK da Klu, Klux, Klan. E então há o argumento de que simplesmente ela era mulher, tinha de morrer. A ideia é sustentada por aqueles que acham que a mulher, no Brasil dos anos 1970 e 1980, liberada pela década anterior, não foi feita para perdurar em regime promíscuo. Serve como símbolo. E tendo atuado sua parte de prostituta do sistema, morre a fim de pagar seus pecados. De todos os nomes do ecletismo musical tornado famoso pela explosão do udigrúdi pós-tropicalista, o de Neide era certamente o menos conhecido. Não quis ser símbolo de nada nem levantou bandeira de movimento nenhum. Neide estava fora do sistema e, por assim dizer, fora da contracultura. Atuava naquela órbita periférica que os críticos da época chamavam de Música Barata, espécie de lúmpen-rock. Ela própria usou o termo, cantou essa expressão. Neide Laet é aquela dona esforçada, de vida dura e sem filosofia, beberrona, mamãe libertina, cuja entrega total aos sentidos encarna as aspirações emocionais mais profundas de sua geração.
Em Montreux ela saiu de colante cor da pele, descalça, com rabo de cavalo. E Mão, de calça branca boca de sino, sapatos plataforma-alta e camiseta psicodélica. Os dois se olhavam, dividindo o microfone. No contrabaixo ficava Murtinho. Roberto Cozzo na bateria e na percussão. Juntos faziam a Música Barata da Banda Menor, $M B B M$, eme bebê hm, numa piada com a cordialidade à uisquinho da melhor MPB, como estão nas fotos das pichações por onde passavam a banda de Lady Laet.

\section{Capítulo doze}

Curiosamente, no Brasil a Música Barata antecipou o Punk num sentido pragmático, ilustrado pela carreira de Neide. As letras não faziam prognósticos nem davam conselhos. Também não eram um j'acuse melódico e correto segundo nenhuma filosofia. Nem tribuna nem consultório sentimental. Do ponto de vista da forma, o que se fazia em estúdio ia aos shows, a mesma formação, o mesmo estilo e repertório, a mesma economia. Não havia diferença. Não havia produção de espetáculo. Era música e ponto final. Daí a grande presença de palco que se nota em Ladeira, Aposta e Brazil, gravados no estúdio, em som direto, de todo semelhantes àquele registrado ao vivo, em Montreux. O som sujo de Lady era limpo, sem edições nem as camadas do roque sinfônico ou progressivo, sem os truques e overdubs da fase final dos Beatles. O único paralelo era a música folk americana, o blues e o gospel, o primeiro Dylan, para os quais a raiz da música é o seu todo. As canções de Neide Laet são, por isso mesmo, um abraço a um som mundano e já conhecido de todo e qualquer brasileiro.

Mas ao longo da década de 1970 as coisas começaram a mudar. Os estúdios, cada vez mais equipados com mesas multicanais, ofereciam outras possibilidades. Ao mesmo tempo, eram caros, grandes. Houve uma aglutinação, uma concentração deles nas mãos das gravadoras e de multinacionais. RCA, BMG, Capitol, EMI. Os pequenos começaram a desaparecer. Os produtores, a ter mais influência nas gravações. Na década de 1980 sumiram os selos e estúdios menores, de apelo alternativo. Rosemblitz, Guarani, Eldorado, Bandeirante, Calíope, entre tantos outros. E a Som Livre se beneficiou da imensa malha de rádios e emissoras de TV para propagandear os seus LPs de música infantil ou brega, de artistas corretos, integrados, cariocas católicos. Barraram Tim Maia e Lady Laet. Só entrava nesse clube quem tivesse costas quentes, carteira de patriota ou fosse amigo dos homens.

\section{Papo número um}

Saboia disse que o que eu tinha escrito até agora não era uma biografia, mas um apanhado de vinhetas 
que confundiam o leitor no tempo, porque seguiam num vaivém entre o começo da carreira de Neide Laet e o enigma da sua morte. Estávamos num café, na esquina da Sunset Boulevard. Ele já tinha puxado o assunto de Hani, perguntando se no vídeo do humanoid era mesmo ela, o corpo dela, nu, nua, arrebentando com aquela aparição computadorizada. Eu disse que era e não era ela. Ele falou: Porra, Lucineide, você nunca responde as coisas direito. Pois, é a moça ou não é? E por que o namorado se gaba de propagandear ela nua, numa festa para os amigos? Que putaria é essa?

É arte, Saboia.

Arte o caralho.

Você é muito grosso. Hani só gosta de gente fina, viu?

Como o tatuado canalha, com jeito de cafetão?

Fiz silêncio.

Vamos voltar à conversa?

Ele fez uma cara feia.

Vamos. O problema é que sua biografia não diz nada sobre. A Lady. Que. Eu. Fiz.

A minha mãe?

Eu fiz a artista, Lucineide. E você tem a oportunidade de contar a história dela. Voltar às suas origens. Essa merda toda.

Saboia sacudiu os braços para o alto, deu um tempo, de cara feia, enquanto tomávamos café calados. Depois falou que tinha um material para mim, para o livro. Tirou de dentro de uma mochila jeans uma folha de jornal dobrada em quatro. Era uma página do Diário de Osasco.

\section{Papo número dois}

Você leu a entrevista, não leu? Sabe o que mudou? Li, mas falei que não sabia. Saboia respondeu: Todo mundo começou a ver, depois de Sargent Pepper, que a experiência de palco era um mundo totalmente diferente da de estúdio. Escrever as canções passou a ser menos importante do que produzir os discos. O som era penteado em mesas multicanais, com overdubs, takes diferentes, vozes dobradas, cordas, sino, vaca mugindo. Tudo isso escondia a falta de talento de quem tinha pouco a dar. As mesas passaram rápido de dois canais a quatro, e, depois, a oito, doze, dezesseis. Dylan gravava em quatro canais e pronto. Lady pegava por aí. Os Beatles montavam camadas de overdubs numa mesa de quatro canais usando pingue-pongue, ou seja, você bota para toca a fita master, de dois canais, enquanto a banda toca por cima, em mais dois canais. Daí repete a coisa, tocando o overdub prégravado por cima de outra pegada da banda. Depois mixa tudo em mono ou num estéreo simples. Fica parecendo que de dois microfones saíram dezesseis vozes. Mas Mão, o tal Gaviria, que fazia as harmonias para Lady, ele era diferente, Saboia disse, e bateu com a unha do dedo na folha de jornal dobrada em cima da mesa. Depois continuou: Mão tocava com acordes quebrados, as notas picadas, usava os inteiros na parte do solo, quando a guitarra saía. Botava o amplificador Marshall com eco. Metia os pedais delay, overdrive, super overdrive e uauá. Cada pedacinho que você ouvia significava alguma coisa. Dava pra escutar tudo. Viu a diferença? A Banda Menor não fazia empastelamento do som.

O que é que isso tem a ver com Neide?

Tem que o que ela escrevia era cristalino, como as harmonias de Mão.

Eles eram um casal, Saboia?

Que merda, Lou-see. Naquela época todo mundo era um casal.

É pra eu falar isso no livro?

Agora fodeu. Você pensa o quê, que Mão é seu pai? De novo isso? Meta se quiser no livro. A mãe é sua. Mas acho importante aquela foto.

Não sei, respondi. Acho que vou tirar um tempo.

Um tempo? Um tempo, como assim?

Vou viajar com Hani. Ela quer ver o pai, que vem dar uma palestra em Berkeley.

Putz, Lucineide.

São só uns dias, Saboia, eu disse.

E ele fechou os olhos, levantou o queixo e fez aquela cara de morte.

Recebido: 04/03/17

Aprovado: 02/04/17

Contato: passos@humnet.ucla.edu 